Roczniak Katarzyna, Babuśka-Roczniak Magdalena, Wojtanowska-Kaczka Magdalena, Racz Oliver, Roczniak Anna, Lyubinets Oleh, Widuchowski Wojciech, Roczniak Wojciech. Morphological and motor skills condition among 10- 11 year old children engaged in cross-country skiing attending Sports Primary School in Suprasl. Journal of Education, Health and Sport. 2020;10(6):68-81. eISSN 2391-8306. DOI http://dx.doi.org/10.12775/JEHS.2020.10.06.007

https://apcz.umk.pl/czasopisma/index.php/JEHS/article/view/JEHS.2020.10.06.007

https://zenodo.org/record/3884524

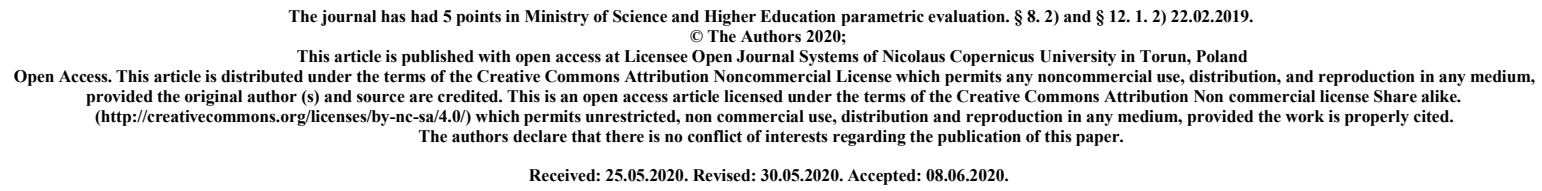

\title{
Morphological and motor skills condition among 10- 11 year old children engaged in cross-country skiing attending Sports Primary School in Suprasl
}

Stan cech morfologicznych i zdolności motorycznych 10- 11 letnich dzieci uprawiających biegi narciarskie w Sportowej Szkole Podstawowej w Supraślu

\author{
Katarzyna Roczniak ${ }^{1}$, Magdalena Babuśka-Roczniak ${ }^{2}$, \\ Magdalena Wojtanowska-Kaczka ${ }^{2}$, Oliver Racz ${ }^{3}$, Anna Roczniak ${ }^{1}$, Oleh Lyubinets ${ }^{4}$, \\ Wojciech Widuchowski ${ }^{5}$, Wojciech Roczniak ${ }^{2}$
}

${ }^{1}$ New World of Physiotherapy, Suprasl, Poland

${ }^{2}$ The Jan Grodek State University in Sanok, Poland

${ }^{3}$ University of Pavol Jozef Safarik, Kosice, Slovak Republic

${ }^{4}$ Danylo Halytsky Lviv National Medical University, Lviv, Ukraine

${ }^{5}$ District Hospital of Orthopaedics and Trauma Surgery in Piekary Śląskie, Piekary Śląskie, Poland

Corresponding author Prof. Wojciech Roczniak wojciech_roczniak@interia.pl 


\section{Abstract}

Introduction. Cross-country skiing is a sport discipline with different applications in the modern world. It is used in recreation, rehabilitation, tourism and sport as a phycical movement.

Objective of the work. The aim of the study was to estimate physical fitness of children aged 10 - 11 years attending sports classes (cross-country skiing profile) with the results of the efficiency grade among students attending unsportsmanlike classes in Sports Primary School in Suprasl.

Material and methods. The study involved 50 children attending the Sports School in Suprasl - class 4 students. Each student was supposed to take part in the International Physical Fitness Test. There were the following attempts: 50 metres run, long jump, sitting position from lying down during 30 seconds, the trunk-bend in front and 600 metres run. The results of completed studies are presented in tables and figures below.

Results. The analysis show that girls practising cross-country skiing are characterized by higher efficiency motor skill compared to their peers, as well as it is easier for them to acquire new motor skills than for boys of their class. For boys the differences that occurred between sports and unsportsmanlike classes was insignificant. Perhaps, it may change in future.

Conclusions. Children attending sports classes (cross country-skiing profile) have better motor abilities and acquire new motor skills faster than pupils in unsportsmanlike classes.

\section{Abstrakt \\ Cel pracy}

Celem pracy było określenie stanu sprawności fizycznej dzieci w wieku 10 - 11 lat uczęszczających do klasy sportowej (profil narciarstwo biegowe) na tle wyników sprawności uczniów klas niesportowych w Sportowej Podstawowej Szkole w Supraślu

\section{Material i metody}

W badaniu wzięło udział 50 dzieci uczęszczających do Sportowej Szkoły Podstawowej w Supraślu - uczniowie klasy IV (20 dzieci z klasy sportowej oraz 30 z klasy niesportowej). Każdy z badanych miał za zadanie wzięcie udziału w Międzynarodowym Teście Sprawności Fizycznej. Były to: biegu na 50 metrów, skoku w dal z miejsca, siadu z leżenia tyłem w czasie 30 sekund, skłonu tułowia w przód oraz biegu na 600 metrów. Próby te są przeznaczone do oceny sprawności fizycznej dzieci do 12 roku życia. Analizy statystyczne przeprowadzono przy użyciu programu STATISTICA 13.1. Otrzymane rezultaty zrealizowanych badań przedstawione zostały $\mathrm{w}$ tabelach oraz rycinach.

\section{Wyniki}

Z przeprowadzonej analizy wynika, że dziewczęta uprawiające narciarstwo biegowe odznaczają się wyższą sprawnością motoryczną w porównaniu do swoich rówieśniczek, a także łatwiej przychodzi im nabywanie nowych umiejętności motorycznych niż chłopcom z ich klasy. W przypadku chłopców różnice, jakie wystąpiły między klasami niesportowymi, a klasą sportową były nieznaczne. Nie wyklucza się, że w niedalekiej przyszłości to się zmieni. 


\section{Wnioski}

Dzieci uczęszczające do klas o profilu sportowym (narciarstwo biegowe) odznaczają się wyższymi zdolnościami motorycznymi w stosunku do uczniów klas niesportowych oraz szybciej nabywają nowych umiejętności motorycznych.

Key words: motor skills, cross-country skiing, sports classes, unsportsmanlike classes.

\section{Słowa kluczowe: umiejętności motoryczne, narciarstwo biegowe, zajęcia sportowe, zajęcia niesportowe.}

\section{INTRODUCTION}

Cross-country skiing is a sport discipline with different applications in the modern world. It is used in recreation, rehabilitation, tourism and sport as a physical movement [1]. Cross-country skiing is a discipline that requires strong commitment and self-denial from the player. The athlete who trains cross-country skiing forms mainly their physical ability which is the resistance [2]. Cross-country skiing has a great impact on strength and resistance through a training process. This leads to the ability of competition in different sports disciplines including both long distances (different for each age category), as well as sprints. It is important for this discipline the frequent use of fartlek, as a training and changable method. The basic method is a continuous method with constant intensity. Increasingly popular method is interval training which allows for quick development of strength, but also force [3].

The coaches recruiting young students to sports classes focus on the motor ability, which is characteristic for children [4].

The motor ability is the ability to perform physical activities and the degree of the achievement of specific motor tests, which are determined by motor skills and abilities. The motor capacity consists of two components, which are the motor abilities and motor skills, as well as interrelationships that exist between [5,6]. The skills and the abilities are highly dependent on each other. This is confirmed by the fact of externalizing of motor skills. Motor skill (motor characteristics) is defined as a set of conditions having common movement and biological base, which are influenced by genetic and environmental factors (which are in mutual interaction). According to popular classification, motor abilities include the following three groups: stamina (power, high-speed, strength and flexibility), coordinate (motion control, learning motor adaptation) and the complex of two already mentioned [7, 8].

Motor development of children is a key determinant of their physical development. This is a process that pays the most attention when assessing the overall development of young people. There is a theory based on research results between the child and its motor abilities - children having weak motor skills are at greater difficulty in adapting to the requirements of the school. At the same time pupils active and characterized by excessive irritability have greater problems with focusing on a particular task [9, 10, 11, 12].

During the fitness exams, the students of class 3 are involved in the following: long jump, baseball, throw a ball bat, throw the medicine ball weighing $1 \mathrm{~kg}$, running for 30 and 500 metres. With these tests the coaches can determine the future competitors, as well as observe their motor skills which are already the clue to the development of training process 
$[13,14]$. A huge impact on the effectiveness of sports activities in cross-country skiing is also visual - motor coordination, thermoregulation, body type, water - electrolyte economy, psychological factors, tactics, etc. [15].

\section{AIM OF THE RESEARCH}

The aim of the study was to estimate physical fitness of children aged $10-11$ years attending sports classes (cross-country skiing profile) with the results of the efficiency grade among students attending unsportsmanlike classes in Sports Primary School in Suprasl.

\section{MATERIAL AND METHOD}

In this study class 4 students of Sports School in Suprasl were involved. There are three classes at a given level of teaching: sports one (cross-country skiing profile) and the other two unsportsmanlike classes. The study was carried out in April and May 2019.

In total, the study involved 50 students, including 20 students of sports class - 10 girls and 10 boys. Besides, there were 30 students attending unsportsmanlike classes including 21 girls and 9 boys.

In the research the multiple selected samples from the International Physical Fitness Test (MTSF) were used. They are designed for children up to 12 years old: 50 metres run, long jump, sitting position from lying down during 30 seconds, the trunkbend in front and 600 metres run.

On the basis of the tests results, the statistical analysis were made using STATISTICA programme 13.1. Calculations were performed of the arithmetic mean, standard deviation and Student - $t$ test for independent groups specifying whether any difference is statistically significant $(p>0.05)$. The results of the research and statistical analysis are presented in the tables and figures below. 


\section{RESULTS}

The results in the sample at 50 metres run are not statistically significant $(p>0.05)$ between girls attending sports classes and unsportsmanlike classes.

Table 1. The t-test - 50 metres run among girls in sports and unsportsmanlike classes.

\begin{tabular}{|c|c|c|c|c|c|c|c|c|c|c|}
\hline $\begin{array}{c}\text { Średnia } \\
\text { Grupa 1 }\end{array}$ & $\begin{array}{l}\text { Średnia } \\
\text { Grupa 2 }\end{array}$ & $\mathrm{t}$ & $\mathrm{df}$ & $\mathrm{P}$ & $\begin{array}{c}\text { Nważnych } \\
\text { Grupa 1 }\end{array}$ & $\begin{array}{c}\text { Nważnych } \\
\text { Grupa 2 }\end{array}$ & $\begin{array}{c}\text { Odch.std } \\
\text { Grupa 1 }\end{array}$ & $\begin{array}{c}\text { Odch.std } \\
\text { Grupa 2 }\end{array}$ & $\begin{array}{c}\text { iloraz F } \\
\text { Wariancje }\end{array}$ & $\begin{array}{c}\text { P } \\
\text { Wariancje }\end{array}$ \\
\hline 9,345000 & 9,257143 & 0,480674 & 29 & 0,634354 & 10 & 21 & 0,465672 & 0,480179 & 1,063276 & 0,973521 \\
\hline
\end{tabular}

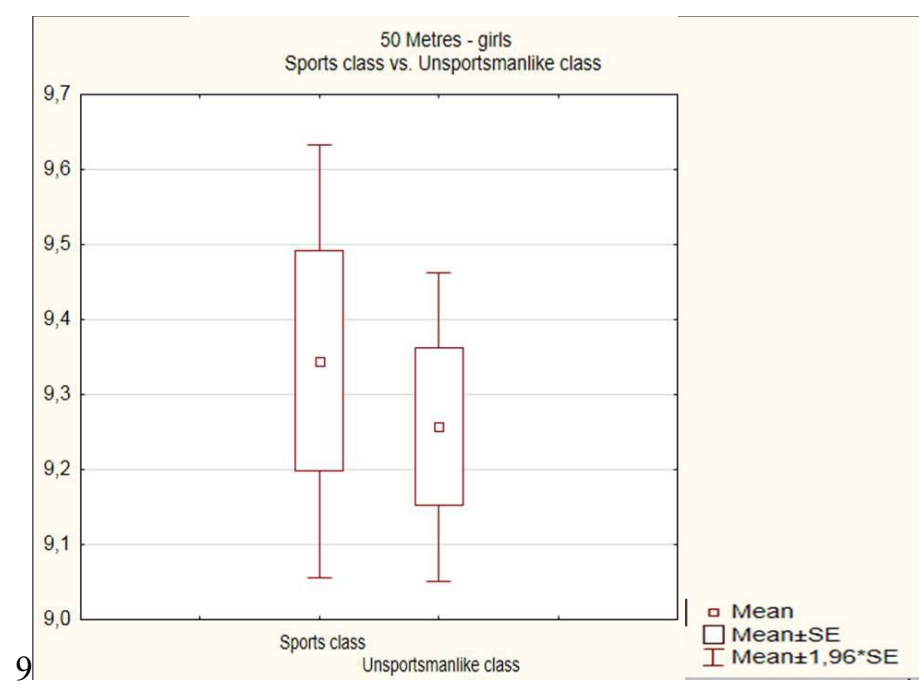

Figure 1. 50 metres run -girls.

The results of the boys running for 50 metres, shown by Fig. 2 are not statistically significant. However, the results among boys in unsportsmanlike classes are far more similar to each other than the results obtained with the boys attending sports classes. 
Table 2. Test $\mathrm{t}$ - 50 metres run among boys in sports and unsportsmanlike classes.

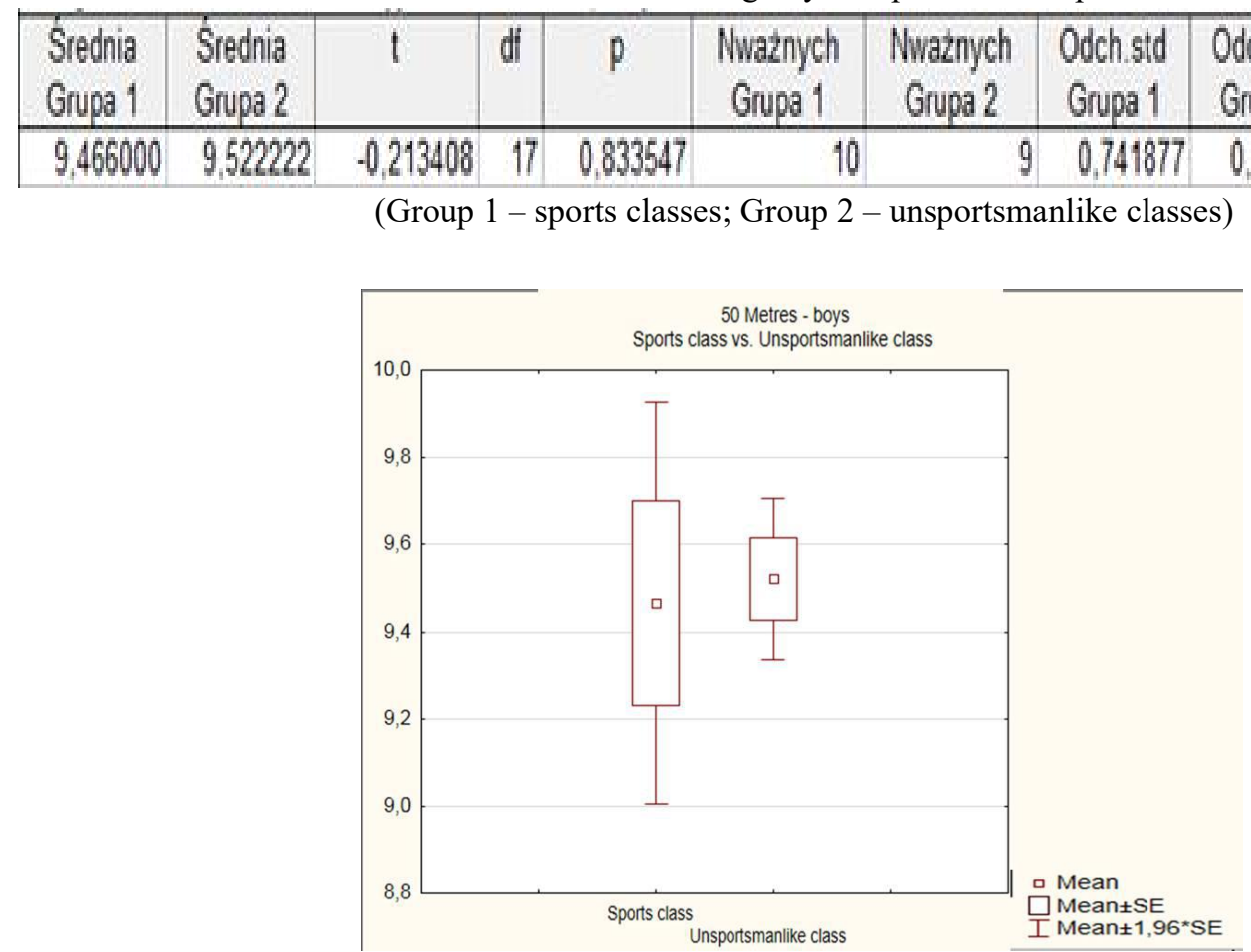

Figure 2. 50 metres run - boys.

The results of the trunk-bend in front of girls are statistically significant $(p<0.05)$. Better results were obtained from schoolgirls attending sports classes. Picture 3 shows the results, which in the case of sports classes are more similar to each other than in girls attending unsportsmanlike classes.

Table 3. The t-test - trunkbend in front among girls in sports and unsportsmanlike classes.

\begin{tabular}{|c|c|c|c|c|r|r|r|r|r|r|}
\hline $\begin{array}{c}\text { Średnia } \\
\text { Grupa 1 }\end{array}$ & $\begin{array}{l}\text { Średnia } \\
\text { Grupa 2 }\end{array}$ & $t$ & df & $P$ & $\begin{array}{c}\text { Nważnych } \\
\text { Grupa 1 }\end{array}$ & $\begin{array}{c}\text { Nważnych } \\
\text { Grupa 2 }\end{array}$ & $\begin{array}{c}\text { Odch.std } \\
\text { Grupa 1 }\end{array}$ & $\begin{array}{c}\text { Odch.std } \\
\text { Grupa 2 }\end{array}$ & $\begin{array}{c}\text { iloraz F } \\
\text { Wariancje }\end{array}$ & $\begin{array}{c}p \\
\text { Wariancje }\end{array}$ \\
\hline 5,400000 & 1,238095 & 2,107396 & 29 & 0,043847 & 10 & 21 & 3,025815 & 5,847262 & 3,734397 & 0,047118 \\
\hline
\end{tabular}

(Group 1 - sports classes; Group 2 - unsportsmanlike classes)

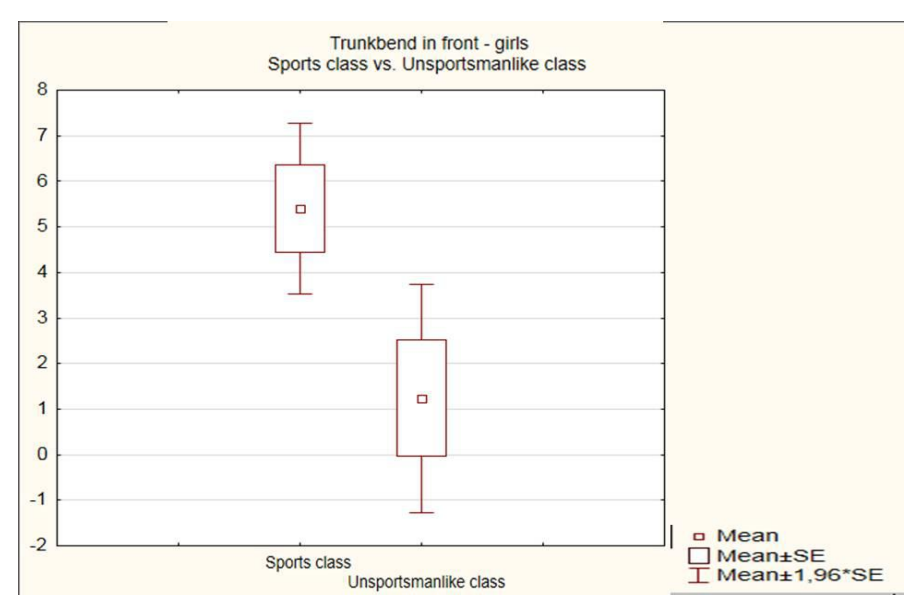

Figure 3. Trunkbend in front - girls. 
The boys' results in the attempt of trunk-bend in front are statistically insignificant ( $\mathrm{p}>0.05)$. A group of boys from the sports class obtained better results, and they are more similar to each other than the results unsportsmanlike classes.

Table 4. The test $\mathrm{t}$ - trunkbend in front among boys in sports and unsportsmanlike classes.

\begin{tabular}{|c|c|c|c|c|r|r|r|c|c|c|}
\hline $\begin{array}{c}\text { Średnia } \\
\text { Grupa 1 }\end{array}$ & $\begin{array}{l}\text { Średnia } \\
\text { Grupa 2 }\end{array}$ & $t$ & $d f$ & $p$ & $\begin{array}{c}\text { Nważnych } \\
\text { Grupa 1 }\end{array}$ & $\begin{array}{c}\text { Nważnych } \\
\text { Grupa 2 }\end{array}$ & $\begin{array}{c}\text { Odch.std } \\
\text { Grupa 1 }\end{array}$ & $\begin{array}{c}\text { Odch.std } \\
\text { Grupa 2 }\end{array}$ & $\begin{array}{c}\text { iloraz F } \\
\text { Wariancje }\end{array}$ & $\begin{array}{c}p \\
\text { Wariancje }\end{array}$ \\
\hline$-2,00000$ & $-6,44444$ & 1,896558 & 17 & 0,075011 & 10 & 9 & 2,905933 & 6,765928 & 5,421053 & 0,020572 \\
\hline
\end{tabular}

(Group 1 - sports classes; Group 2 - unsportsmanlike classes)

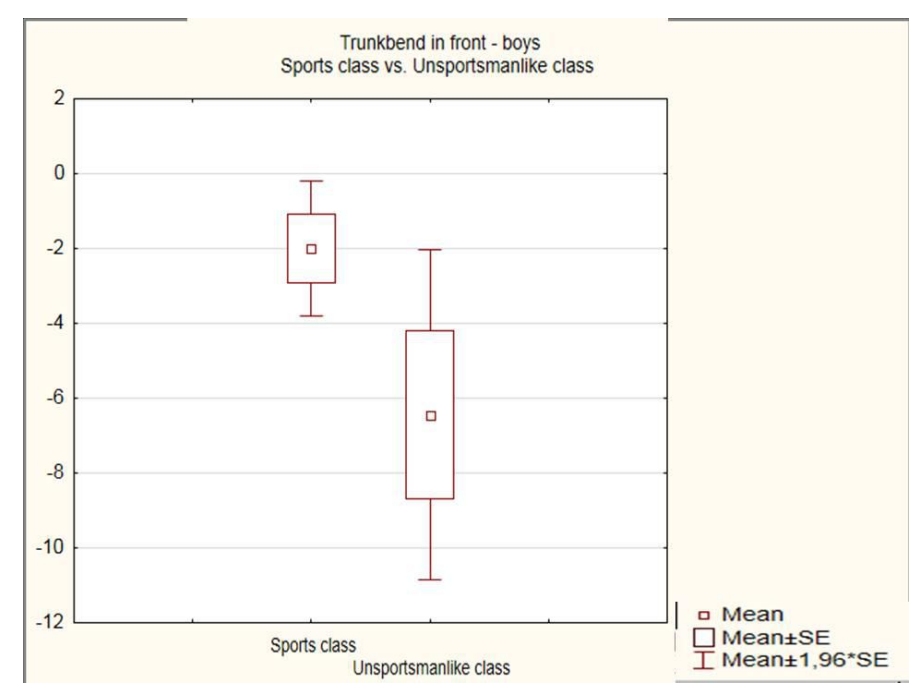

Figure 4. Trunkbend in front - boys.

The girls' results are statistically significant. Schoolgirls attending sports classes achieved better results in the test of sitting position from lying down in 30 seconds. 
Table 5. Test $\mathrm{t}$ - sitting position from lying down during 30 seconds among girls in sports and unsportsmanlike classes.

\begin{tabular}{|c|c|c|c|c|r|r|r|r|r|r|}
\hline $\begin{array}{l}\text { Średnia } \\
\text { Grupa 1 }\end{array}$ & $\begin{array}{l}\text { Średnia } \\
\text { Grupa 2 }\end{array}$ & $t$ & $d f$ & $p$ & $\begin{array}{c}\text { Nważnych } \\
\text { Grupa 1 }\end{array}$ & $\begin{array}{c}\text { Nważnych } \\
\text { Grupa 2 }\end{array}$ & $\begin{array}{c}\text { Odch.std } \\
\text { Grupa 1 }\end{array}$ & $\begin{array}{c}\text { Odch.std } \\
\text { Grupa 2 }\end{array}$ & $\begin{array}{c}\text { iloraz F } \\
\text { Wariancje }\end{array}$ & $\begin{array}{c}p \\
\text { Wariancje }\end{array}$ \\
\hline 23,50000 & 19,14286 & 2,997562 & 29 & 0,005533 & 10 & 21 & 1,715938 & 4,407785 & 6,598383 & 0,006323 \\
\hline
\end{tabular}

(Group 1 - sports classes ; Group 2 - unsportsmanlike classes)

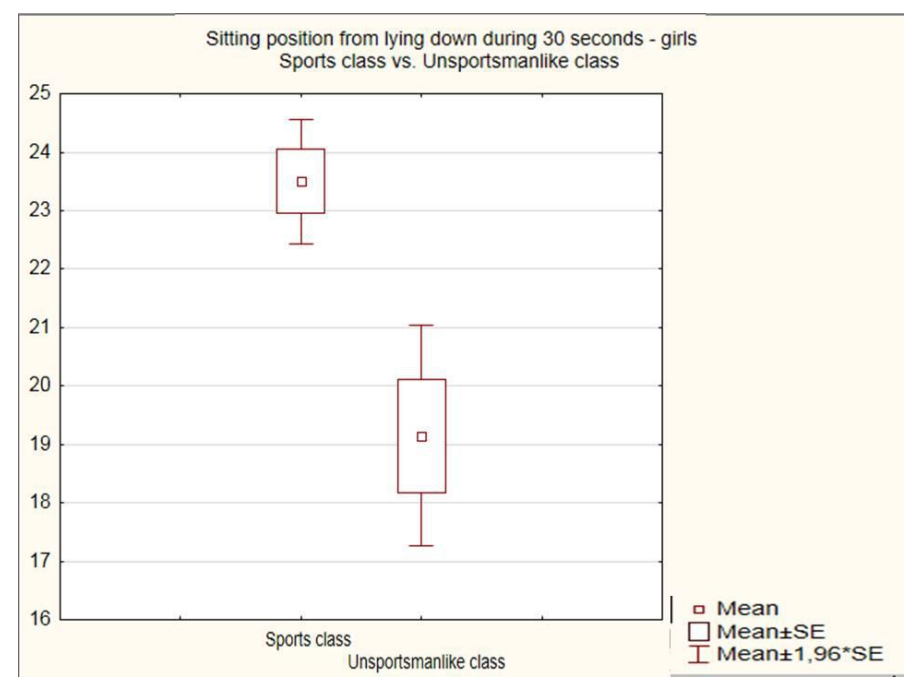

Figure 5. Sitting position from lying down in 30 seconds -girls.

In an attempt of sitting position with lying down the boys' differences are statistically significant $(\mathrm{p}<0.05)$.

Table 6. Test $\mathrm{t}$ sitting position from lying down during 30 seconds among boys in sports and unsportsmanlike classes.

\begin{tabular}{|l|c|c|c|c|c|c|c|c|c|c|}
$\begin{array}{c}\text { Średnia } \\
\text { Grupa 1 }\end{array}$ & $\begin{array}{c}\text { Średnia } \\
\text { Grupa 2 }\end{array}$ & $t$ & df & $p$ & $\begin{array}{c}\text { Nważnych } \\
\text { Grupa 1 }\end{array}$ & $\begin{array}{c}\text { Nważnych } \\
\text { Grupa 2 }\end{array}$ & $\begin{array}{c}\text { Odch.std } \\
\text { Grupa 1 }\end{array}$ & $\begin{array}{c}\text { Odch.std } \\
\text { Grupa 2 }\end{array}$ & $\begin{array}{c}\text { iloraz F } \\
\text { Wariancje }\end{array}$ & $\begin{array}{c}p \\
\text { Wariancje }\end{array}$ \\
\hline 24,00000 & 19,66667 & 3,093588 & 17 & 0,006595 & 10 & 9 & 3,431877 & 2,549510 & 1,811966 & 0,414644
\end{tabular}

(Group 1 - sports classes; Group 2 - unsportsmanlike classes)

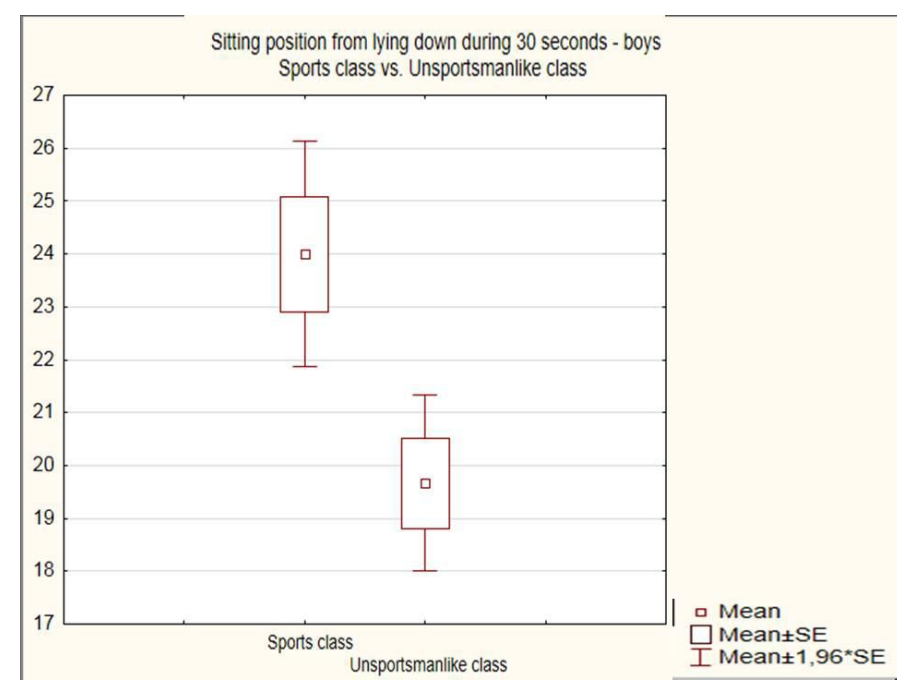

Figure 6. Sitting position from lying down in 30 seconds - boys. 
Differences of results in long jump from Sports Elementary School students are statistically significant. The girls from sports classes achieved better and more consistent results than their competitors attending unsportsmanlike classes.

Table 7. The $t$ test - long jump from place among girls in sports and unsportsmanlike classes

\begin{tabular}{|c|c|c|c|c|c|c|c|c|c|c|}
\hline $\begin{array}{l}\text { Średnia } \\
\text { Grupa } 1\end{array}$ & $\begin{array}{l}\text { Średnia } \\
\text { Grupa } 2\end{array}$ & $t$ & df & $P$ & $\begin{array}{c}\text { Nważnych } \\
\text { Grupa } 1\end{array}$ & $\begin{array}{c}\text { Nważnych } \\
\text { Grupa } 2\end{array}$ & $\begin{array}{l}\text { Odch.std } \\
\text { Grupa } 1\end{array}$ & $\begin{array}{c}\text { Odch.std } \\
\text { Grupa } 2\end{array}$ & $\begin{array}{c}\text { iloraz F } \\
\text { Wariancje }\end{array}$ & $\underset{\text { Wariancje }}{P}$ \\
\hline 159,3000 & 122,4790 & 2,596164 & 29 & 0,014646 & 10 & 21 & 14,23649 & 43,41236 & 9,298667 & 0,001681 \\
\hline
\end{tabular}

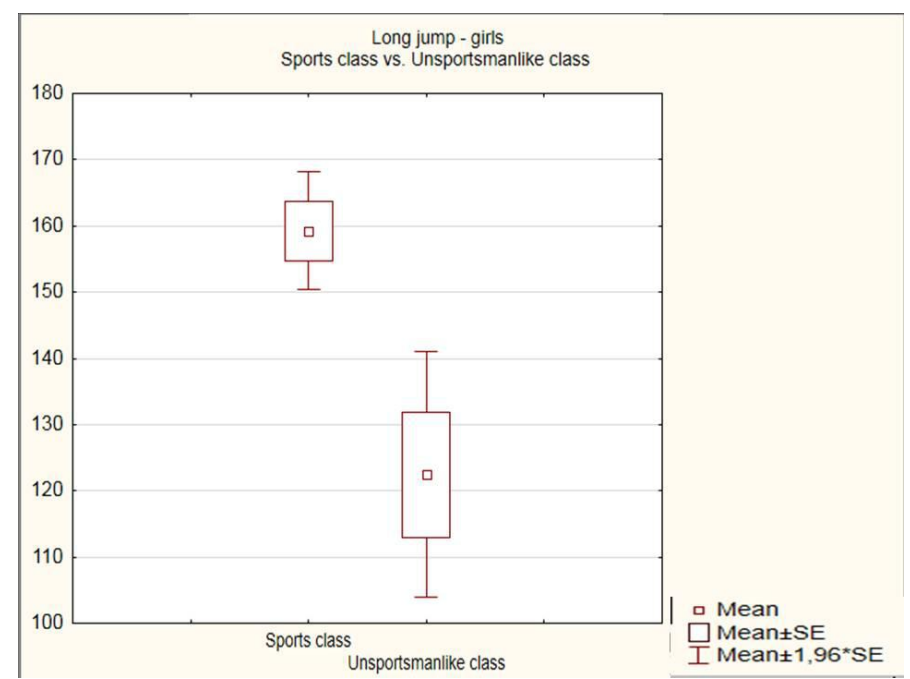

Figure 7. Long jump - girls.

The results of the boys in the long jump are not statistically significant. However, the results of boys attending sports classes are more similar to each other than with their colleagues attending unsportsmanlike classes. 
Table 8. Test t- long jump from place among boys in sports and unsportsmanlike classes.

\begin{tabular}{l|c|c|c|c|c|c|c|c|c|c} 
Średnia & $\begin{array}{c}\text { Średnia } \\
\text { Grupa 1 }\end{array}$ & Grupa 2 & $\mathrm{df}$ & $\boldsymbol{P}$ & $\begin{array}{c}\text { Nważnych } \\
\text { Grupa 1 }\end{array}$ & $\begin{array}{c}\text { Nważnych } \\
\text { Grupa 2 }\end{array}$ & $\begin{array}{c}\text { Odch.std } \\
\text { Grupa 1 }\end{array}$ & $\begin{array}{c}\text { Odch.std } \\
\text { Grupa 2 }\end{array}$ & $\begin{array}{c}\text { iloraz F } \\
\text { Wariancje }\end{array}$ & $\begin{array}{c}p \\
\text { Wariancje }\end{array}$ \\
\hline 146,3000 & 119,1067 & 1,680785 & 17 & 0,111084 & 10 & 9 & 21,84821 & 45,80166 & 4,394714 & 0,040448 \\
\hline
\end{tabular}

(Group 1 - sports classes; Group 2 - unsportsmanlike classes)

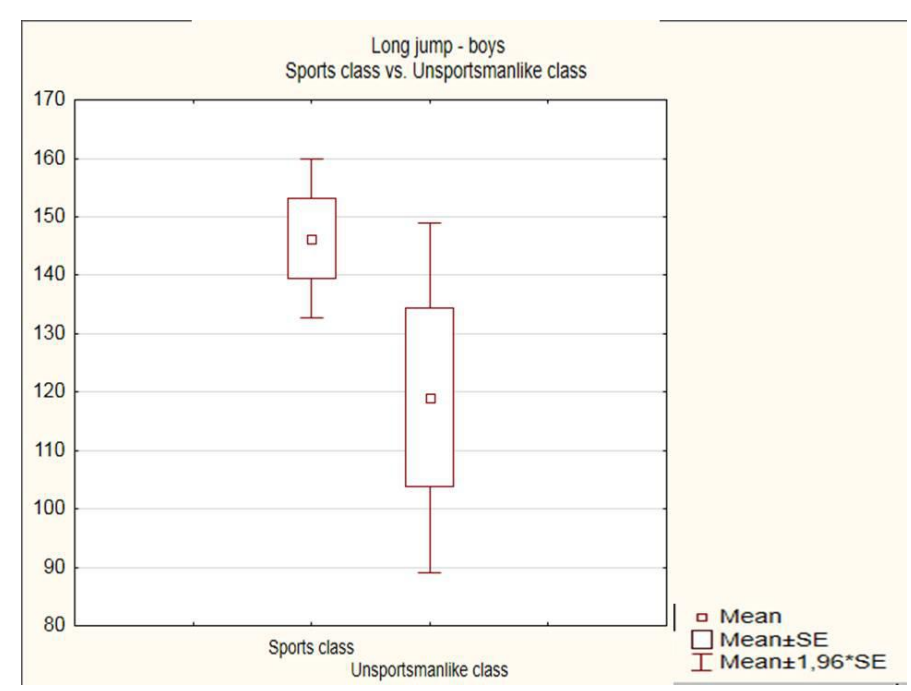

Figure 8. Long jump - boys.

Results shown on Figure, girls running at 600 metres, the differences between classes are statistically significant $(\mathrm{p}<0.05)$. The girls practising cross-country skiing in the sport class performed significantly better than their competitors from unsportsmanlike classes.

Table 9. Test $\mathrm{t}$ - 600 metres run among girls in sports and unsportsmanlike classes

\begin{tabular}{c|c|c|c|c|c|c|c|c|c|c}
\hline $\begin{array}{l}\text { Średnia } \\
\text { Grupa 1 }\end{array}$ & $\begin{array}{l}\text { Średnia } \\
\text { Grupa 2 }\end{array}$ & $\mathrm{t}$ & $\mathrm{df}$ & $\mathrm{p}$ & $\begin{array}{c}\text { Nważnych } \\
\text { Grupa 1 }\end{array}$ & $\begin{array}{c}\text { Nważnych } \\
\text { Grupa 2 }\end{array}$ & $\begin{array}{c}\text { Odch.std } \\
\text { Grupa 1 }\end{array}$ & $\begin{array}{c}\text { Odch.std } \\
\text { Grupa 2 }\end{array}$ & $\begin{array}{c}\text { iloraz F } \\
\text { Wariancje }\end{array}$ & $\begin{array}{c}\mathrm{p} \\
\text { Wariancje }\end{array}$ \\
\hline 2,591000 & 3,494762 & $-3,35806$ & 29 & 0,002209 & 10 & 21 & 0,361246 & 0,807927 & 5,001929 & 0,017396 \\
\hline \multicolumn{8}{c|}{ (Group 1- sports classes; Group 2 - unsportsmanlike classes) }
\end{tabular}

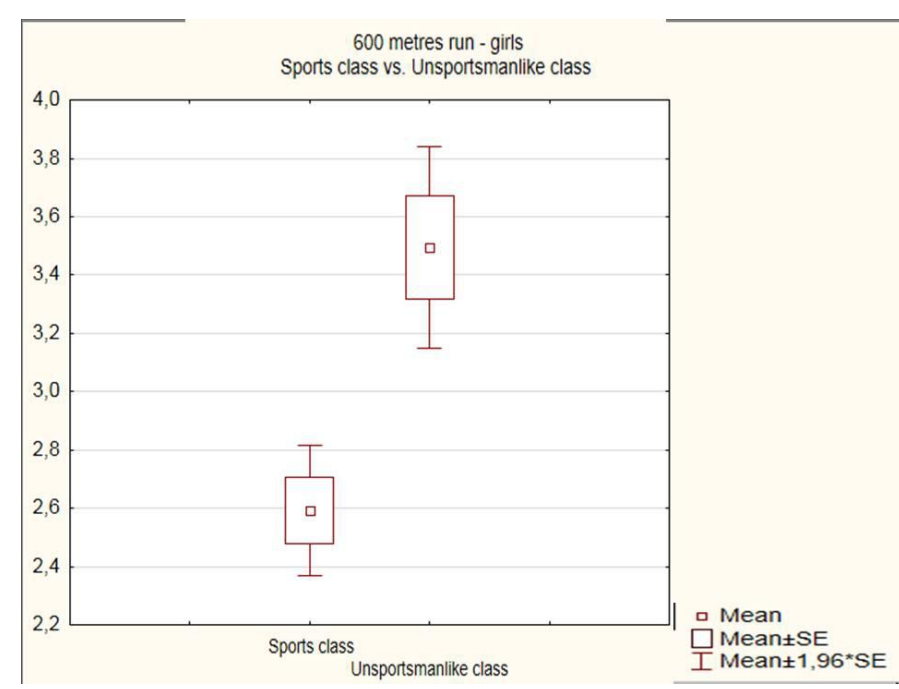

Figure 9. 600 metres run -girls. 
The results obtained and presented in Figure 18 are statistically insignificant ( $>>0.05)$. However, the boys from sports classes obtained better results than the students from unsportsmanlike classes.

Table 10. The t-test - 600 metres run among boys in sports and unsportsmanlike classes

\begin{tabular}{c|c|c|c|c|c|c|c|c|c|c}
\hline $\begin{array}{l}\text { Średnia } \\
\text { Grupa 1 }\end{array}$ & $\begin{array}{c}\text { Średnia } \\
\text { Grupa 2 }\end{array}$ & $t$ & df & $p$ & $\begin{array}{c}\text { Nważnych } \\
\text { Grupa 1 }\end{array}$ & $\begin{array}{c}\text { Nważnych } \\
\text { Grupa 2 }\end{array}$ & $\begin{array}{c}\text { Odch.std } \\
\text { Grupa 1 }\end{array}$ & $\begin{array}{c}\text { Odch.std } \\
\text { Grupa 2 }\end{array}$ & $\begin{array}{c}\text { iloraz F } \\
\text { Wariancje }\end{array}$ & $\begin{array}{c}p \\
\text { Wariancje }\end{array}$ \\
\hline 2,947000 & 3,490000 & $-1,81413$ & 17 & 0,087347 & 10 & 9 & 0,781097 & 0,464139 & 2,832133 & 0,157485 \\
\hline \multicolumn{8}{c}{ (Group 1 - sports classes; Group 2- unsportsmanlike classes) }
\end{tabular}

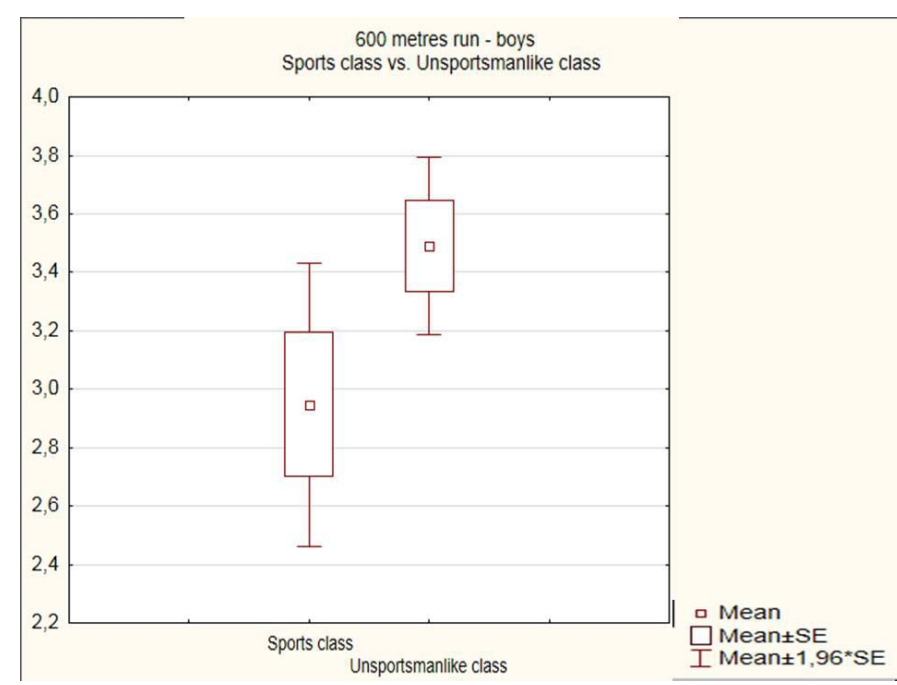

Figure 10. 600 metres run -boys.

\section{DISCUSSION}

Motor ability among children in the twenty-first of century is diversed. This is due to many factors, one of the most important is to practice various types of physical activity. The aim of the discussion was the desire to confront existing knowledge of research that could be carried out among children starting their adventure with skiing race.

Cross-country skiing, as a niche sport in Poland is not very popular topic of Polish scientific literature, so you should explore this topic. With this in mind, the research has been carried out that aimed to determine the status of motor skills of children undergoing extended PE program and those who participated in the standard classes this subject.

In all attempts, the girls attending sports classes achieved better results than those from unsportsmanlike classes. When the tests have been done, their motor abilities belonging to the physical condition were identified [16]. In four of five trials the differences in the results obtained were statistically significant. Only 50 metres run proved to be statistically insignificant in my research. During an increased amount of physical activity, the girls acquire better motor skills, which has a direct effect on the motor performance results.

The most notable difference between the two groups is running at 600 metres. Strength is developed well at the age of girls they are. The research proved, the girls from the sports classes have motor ability better developed. It is rather due to the nature of the crosscountry skiing discipline which requires mainly endurance.

The motor ability that the girls from sports classes show is a dynamic force. In tests of sitting position with lying down within 30 seconds and long jump young skiers have shown 
better motor performance. Also in this case, indirect relationship between cultivated ski racing, and the development of strength can be found. It is sport developing endurance capabilities mainly, as well as the strength endurance. During the cross-country skiing the whole body is engaged in the action. Here, keeping strength is extremely important when competing sports. Core muscles are the basis to maintain a stable position slope. During trainings, the trainers of 10-11 year old children pay great attention to the technical elements, as they form the basis for achieving high sports results. The use of variety of training, which include dynamic exercises to develop force is an imitation. It is training during which ski footsteps are copied. This situation requires concentration and imagination from trainees in order to be able to perform exercises properly. This may affect better results by competitors. Moreover, as Napoleon Wolański pointed out, the development of motor skills at the age of tested girls is dynamic [17].

Test results defining flexibility are low comparing to the study published in 2012 among girls practising modern dance, as well as their peers not practising any sport [18]. The differences between them are approximately $15 \mathrm{~cm}$ comparing to the girls from the sports classes and $19 \mathrm{~cm}$ with pupils attending unsportsmanlike classes. Now, it is clear that the two groups from the Sports School in Suprasl should effectively develop their motor ability. Besides, the study over 7 year old children from the rural area of the county of Dzierzoniow published in 2013 revealed that flexibility is often problematic among young children. The reason for this can be the sciatic muscle contractures - tibial, and also reduced mobility of the lumbar spine [19]. It leads to conclusions for an important aspect of stretching, which is seen while dancing, however, forgotten during other activities. Also, corrective gymnastics teachers pay particular attention to posture and flexibility of the body.

The final tested motor capacity was speed. This capacity was found to be statistically insignificant. It was checked by 50 metres run. The speed rate at a given age is not a feature that develops in a dynamic way. Cross-country skiing is not a group of sport that has a direct impact on the development of that motor abilities. Both of these issues may be reasons such small difference between the two groups - all on the same level form a highspeed capability.

To sum up, the girls from sports classes have better motor performance than their competitors from other branches. In particular, strength and power proved to be the ability, over which the girls from unsportsmanlike classes significantly dominate. This may be due to the fact the implementation of sports class children in cross-country skiing. During cross-country skiing trainings all of the mentioned motor skills are shaped.

The differences between the boys attending sports classes, cross-country skiing profile, and their peers from other classes are not so clear as in the case with their school colleagues. The boys scored significantly better results only in the sample of the sitting position lying back in 30 seconds. In other trials they also achieved better results, but with no statistical meaning. In fact, the boys may have better central stabilization so-called "Core".

What is the influence of achieving results among boys and girls?

The main factor may be so-called girls perfect child's age '[16]. Wieslaw Osiński specified the age range which is $10-11$ years among girls. It is a period of versatility and a very rapid learning of new motor skills. That's why sports class students learning new, more demanding motor tasks, which are the basic elements of cross-country skiing achieve more visible effects 
in motor skills than their competitors from the same school. According to Osinski, boys achieve this stage as girls but two years later. In this connection, we can predict that the differences between boys attending sports classes and their peers may be much larger in future.

Another argument demonstrating small differences between peers who practice cross-country skiing, and do not do it is the assumption of work proportion during the training. It is estimated that $70-80 \%$ of the students training time is comprehensive work [3]. Therefore, the differences achieved by the subjects may be insignificant, because the program of motor development in both groups may be similar.

Cross-country skiing is a sport developing the whole body. Such work causes the body's holistic development. Encouraging the young generation for this sport, we can contribute mainly to the development of strength, and a very important cardio - respiratory endurance. Besides, the sport is highly recommended because of the spread of civilization disease which is obesity.

\section{CONCLUSIONS}

1. Girls practising cross-country skiing at the age of $10-11$ years acquire new motor skills faster than boys.

2. The girls proved significantly higher motor efficiency than their non sportsman competitors.

3. There were no significant differences in motor skills between boys attending sports classes and boys attending unsportsmanlike classes.

\section{LITERATURE}

1. Wojtyczek B., Pasławska M., Klukowski K.: Bezpieczne narciarstwo. Medical Tribune Polska, Warszawa 2014.

2. Kasa J., Gabryś T., Szmatlan- Gabryś U., Görner K.: Wstęp do antropomotoryki dla wszystkich z elementami teorii treningu. PWSZ Oświęcim, Warszawa 2012.

3. Krasicki S., Kowalczyk J.: Narciarstwo biegowe. Wydawnictwo AWF. Kraków 2011.

4. Roczniak W., Babuśka -Roczniak M., Roczniak A., Roczniak R.G.: Kryteria oceny rozwoju motorycznego uczniów szkół podstawowych. Medycyna Ogólna i Nauk o Zdrowiu 2015; 2: 138-141.

5. Fugiel J., Czajka K., Posłuszny P., Sławińska T.: Motoryczność człowieka. Podstawowe zagadnienia $\mathrm{z}$ antropomotoryki. Wyd. 1 popr. i uzup. Wrocław: Wydaw. MedPharm; 2017. ISBN: 978-83-7846-085-5.

6. Wolański N.: Biokulturowe uwarunkowania aktywności motorycznej i rozwoju sprawności człowieka oraz wynikające stąd perspektywy kultury fizycznej. Kultura Fizyczna 2007; 1: $1-11$.

7. Maszczak T.: O międzynarodowym pomiarze aktywności fizycznej. Wychowanie Fizyczne i Zdrowotne 2007: 6: 2 - 3.

8. Rochowicz F.: Wydolność fizyczna - świadomą wartością zdrowia. Wychowanie Fizyczne i Zdrowotne 2008; 6: 12 - 17.

9. Kowaluk - Romanek M., Bieganowska A.: Wczesne wspomaganie dzieci o dysharmonijnym rozwoju psychomotorycznym. Zeszyt naukowe WSSP 2013; 16: 25 - 43. 
10. Popowczak M., Rokita A., Cichy I., Chmura P.: Poziom wybranych koordynacyjnych zdolności motorycznych a wyniki Międzynarodowego Testu Sprawności Fizycznej dzieci w wieku 10 lat. Rozprawy naukowe Akademii Wychowania Fizycznego we Wrocławiu 2013; 40: $86-93$.

11. Zimna - Walendzik E., Kolmaga A., Tafalska E.: Styl życia - aktywność fizyczna, preferencje żywieniowe dzieci kończących szkołę podstawową. Żywność. Nauka. Technologia. Jakość 2009; 4 (65): 195 - 203.

12. Chojnacki K., Tchórzewski D.: Koordynacyjne zdolności a sprawność motoryczna młodzieży uprawiającej sporty zimowe. Wychowanie Fizyczne i Zdrowotne 2009; 2: 32 - 41.

13. Roczniak W., Babuśka - Roczniak M., Wojtanowska M., Roczniak - Zubrzycka A., Cipora E., Konieczny M., Oświęcimska J.M.: Ocena wytrzymałości dzieci kwalifikowanych do klasy o profilu narciarstwo biegowe na tle grupy kontrolnej na podstawie wybranych testów motorycznych. Medycyna Ogólna i Nauki o Zdrowiu 2017; 23 (4): 257 - 262.

14. Roczniak W., Babuśka - Roczniak M., Wojtanowska M., Roczniak - Zubrycka A., Barańska - Januszewska J., Cipora E., Konieczny M., Oświęcimska J.M.: Ocena siły dzieci uprawiających narciarstwo biegowe na tle grupy kontrolnej na podstawie wybranych testów motorycznych. Medycyna Ogólna i Nauki o Zdrowiu 2017; 23 (4): 70 - 75.

15. Chojnacki K., Tchórzewski T.: Koordynacyjne zdolności a sprawność motoryczna młodzieży uprawiającej sporty zimowe. Wychowanie Fizyczne i Zdrowotne 2009; 2: 32 - 41. 16. Osiński W., Raczek J.: Motoryczność człowieka: jej struktura, zmienność i uwarunkowania. AWF, Poznań 2010.

17. Wolański N.: Rozwój biologiczny człowieka: podstawy auksologii, gerontologii i promocji zdrowia. Wydawnictwo Naukowe PWN, Warszawa 2005.

18. Cieślicka M., Napierała M., Pilewska W., Iermakov S.: Stan cech morfologicznych i zdolności motorycznych dziewcząt uczestniczących w zajęciach tańca nowoczesnego. Pedahohika psyxolohiya, ta medyko-biolohichni problemy fizychnoho vyxovannya i sportu 2012; 10: $96-104$.

19. Izydorczyk-Styś A., Izydorczyk-Styś B.: Ocena gibkości dzieci w wieku wczesnoszkolnym. Fizjoterapia 2013; 21 (4): 28 - 34. 